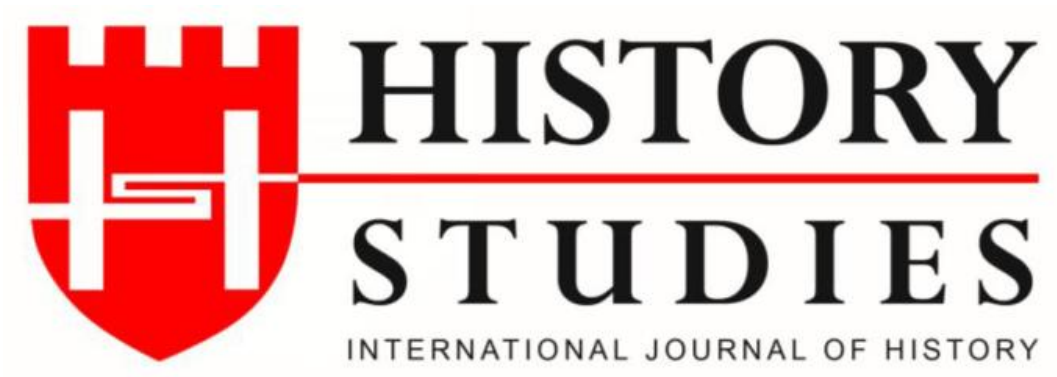

\author{
ISSN: 13094173 (Online) 1309 - 4688 (Print) \\ Volume 11 Issue 1, p. 75-90, February 2019 \\ DOI: $10.9737 /$ hist.2019.708
}

Makalenin Geliş Tarihi: 22.12.2018 - Kabul Tarihi: 17.01.2019

\title{
İmparatorluktan Cumhuriyete Devreden Bir Sorun: Mülkî Taksimat
}

A Long-standing Issue from the Ottoman Empire to the Republic: Civil Administrative Division

\author{
Dr. Murat BURGAÇ \\ ORCID No: 0000-0002-6311-7447 \\ Anadolu Üniversitesi Edebiyat Fakültesi Tarih Bölümü - Eskişehir
}

\begin{abstract}
Öz: 1864 yllında kabul edilen Tuna Vilayet Nizamnamesi'yle, Osmanlı Imparatorluğu'nda o güne kadar süregelen mülkî taksimat değiştirilmiş, eyalet sistemi terkedilerek vilayet sistemine geçilmiştir. Bu yeni mülkî taksimatta; birkaç eyaletin birleşimiyle oluşan vilayetler ülkedeki en büyük cüz'ü tam olarak kabul edilmiş; vilayetler livalara, livalar kazalara ve kazalar da nahiyelere bölünmüştür. Ancak zaman içinde, geniş vilayetlere dayalı bu mülkî taksimatın idarî alanda çeşitli sıkıntılar yarattığ fark edilerek mülkî idare dairelerini daraltma doğrultusunda çalışmalar başlatılmıştır. II. Meşrutiyet Dönemi'nde başlatılan bu çalı̧̧malar, imparatorluğun I. Dünya Savaşı'na girmesi nedeniyle tamamlanamamış böylece bu sorunlu mülkî taksimat, I. Dünya Savaşı sonrası kurulmaya başlanan yeni devlete devretmiştir. Nitekim Ankara'da Büyük Millet Meclisi'nin açılmasıyla başlayan yeni devletin doğuşu sürecinde, Meclisin idare alanında çözmek zorunda olduğu önemli meselelerden biri mülkî taksimatı yeniden yapılandırmak olmuştur. Bu konudaki çalışmalar Cumhuriyet’in ilanindan sonra da devam etmiştir.
\end{abstract}

Bu makalede; imparatorluktan devralınan mülkî taksimatın, niçin değiştirilmek istendiği ve nasıl değiştirildiği, bu değişiklikten sonra ortaya çıkan sıkıntıların neler olduğu, bunları çözme doğrultusunda ne tür adımlar atıldı̆̆ soruları üzerine odaklanılacak ve mülkî taksimatın rasyonel bir şekilde yapılandırllamamasindan kaynaklanan sorunlar irdelenecektir.

Anahtar Kelimeler: Cumhuriyet dönemi, mülkî taksimat, vilayet idareleri, merkeziyetçilik, mahallî idareler.

Abstract: The long-established state system in Ottoman Empire was abandoned and a new provincial system was introduced with Tuna Province Charter in 1864. The provinces which were composed of several states were considered as the largest civil administrative divisions with this charter. In addition, the provinces were divided into 'liva' districts, 'liva's into 'kaza's (smaller counties) and 'kaza's into 'nahiye's (towns).Nevertheless, the new civil administrative division which was highly based on larger provinces appeared to cause various problems in civil administration. Therefore, some efforts towards narrowing the civil administrative bodies were introduced in time. These efforts which had already started in Constitutional Monarchy Period II could not be completed due to Empire's entering World War I so the issue of civil division was transferred to Turkish Republic, which was about to be founded soon after the war. As a matter of fact, reorganizing the civil division appeared to be one of the issues in civil administration to be solved by the National Assembly in Ankara at the outset of the Turkish Republic. The efforts to solve the issue continued after the proclamation of the republic.

The main purpose of the study is to examine why and how the inherited civil administrative division from the imperial period was changed. In addition, the problems following these changes and initiatives to overcome them are highlighted. Finally, the problems appeared due to irrational structuring of the civil division were scrutinised.

Keywords: Period of Republic, civil administrative division, provincial administration, centralisation, local administration. 


\section{Giriş}

Her devlet, kendi toprakları üzerinde hakimiyet kurmak ve devlet görevlerinin yerine getirilebilmesini sağlamak amacıyla bir idare teşkilatı kurar. Bu teşkilatın görev ve yetki sahalarını belirtmek için ayrıldığı bölümlere ise mülkî idare bölümleri ya da başka bir deyişle mülkî taksimat denir. Bu bölümler, birbirine bağlı olmak üzere büyükten küçüğe doğru daha ufak kademelere ayrılır. Mülkî idare bölümleri belirlenirken; bir taraftan devlet işlerinin etkili ve verimli bir şekilde yürütülebilmesini sağlayacak, diğer taraftan ise vatandaşın devletle ilgili işlerinde ve tüm iktisadi ilişkilerinde en yararlı ve verimli olacak şeklin bulunması gerekir. Dolayısıyla her devlet ülkedeki idare bölümlerini, bu amaçlara en iyi şekilde ulaşabilmeyi mümkün k1lacak şekilde düzenlemeye gayret eder. ${ }^{1}$

Türk idare tarihinde bu konudaki en önemli adım, 7 Kasım 1864'de Tuna Vilayet Nizamnamesi'nin ${ }^{2}$ çıkarılmasıyla atılmış ve Niş, Vidin, Silistre eyaletleri birleştirilerek, Tuna Vilayeti adıyla yeni bir mülkî yönetim kademesi oluşturulmuştur. Nizamnamenin gerekçesini oluşturan beyannameye göre, bu değişikliğe gidilmesinin altında yatan temel sebep; ülkedeki idarî ve malî işlerin düzenli görülebilmesini, imar faaliyetlerinin hızlı bir ş̧ekilde yürütülebilmesini, ülkenin kısa zamanda daha mamur hale gelmesini sağlayabilmektir. ${ }^{3}$

1864'ten itibaren Tuna'da uygulamaya geçirilen yeni vilayet usulünün başarılı sonuçlar vermesi üzerine vilayet sistemi ülke geneline yaygınlaştırılmış; ${ }^{4} 1871$ yılında da "İdare-i Umumîye-i Vilayet Nizamnamesi" kabul edilerek sistemde bir takım yeni düzenlemeler yapılmıştır. ${ }^{5}$ Osmanlı Devleti' nin mülkî taksimatını yeniden yapılandırılan bu nizamnamelerle birlikte, o güne kadar ülkedeki en büyük cüz'ü tam olan eyaletler; yerlerini, birkaç eyaletin birleştirilmesiyle oluşturulan vilayetlere bırakmıştır. ${ }^{6}$ Yeni taksimata göre; vilayetler livalara, livalar kazalara, kazalar da nahiyelere ayrılmaktadır. Vilayetlerin idaresinden ise "vali" sorumludur. $^{7}$

\section{Meşrutiyet Döneminde Yaşanan Değişim}

Vilayet sistemine geçiş, II. Mahmut döneminden itibaren başlayan ve Tanzimat döneminde artarak devam eden sıkı merkeziyetçiliğin neden olduğu aksamalara bir çözüm olarak düşünülmüştü. Nitekim vilayet sisteminin fikir babası olan Fuad Paşa'ya göre;

${ }^{1}$ İsmail Hakkı Göreli, İl İdaresi, Ankara Üniversitesi Siyasal Bilimler Fakültesi Yayınları, Ankara 1952, s. 3.

${ }^{2}$ Nizamnamenin tam metni için bkz., Maliye Bakanlığ Bütçe ve Mali Kontrol Genel Müdürlüğü, Vilayet ve Mahallî İdareler Mevzuatı (1864-1996), Maliye Bakanlığ Yayınları, Ankara 1997, s. 1-16.

${ }^{3}$ Mefahir Behlülgil, Imparatorluk ve Cumhuriyet Dönemlerinde İllerimiz, Özal Matbaası, İstanbul 1992, s. 139.

${ }^{4}$ Talat Mümtaz Yaman, "Osmanlı İmparatorluğu Mülkî İdaresinde Avrupalılaşma” İdare, Yı1:13, S.142, İkinci kanun (Ocak) 1940, s. 1485-1487.

51871 nizamnamesi kendisinden önceki nizamnameyi kaldırmıordu. Bu nizamname; vilayet sisteminin uygulanması sırasında görülen eksiklikleri tamamlamak, bu sisteme geçişle birlikte yeni oluşan idare teşkilatının, bu teşkilat içindeki kişi ve kurumların görev ve sorumluluklarını ayrıntıları ile açıklamak amacıyla çıkarılmış bir nizamnameydi. Behlülgil, age., s. 150, 151. Nizamnamenin tam metni için bkz., Maliye Bakanlığı Bütçe ve Mali Kontrol Genel Müdürlüğü, age., s. 26-52.

${ }^{6}$ İlber Ortaylı, "Tanzimat Döneminde eyaletlerin adı değiştirilerek "vilayet" oldu. Değişiklik bu kadarla da sinırlı değildi, sinırlar daraltılmıştı." demektedir. İlber Ortaylı, Tanzimat Devrinde Osmanlı Mahallî İdareleri (18401880), TTK Yayınları, Ankara 2000, s. 61. Musa Çadırcı da "Geniş toprakları kapsayan eyaletler bölünerek küçültülmüş, bununla birlikte isim değişikliğine gidilmiştir. Eyalet, vilayet olmuş(tur.)” demektedir. Musa Çadırc1, Tanzimat Sürecinde Türkiye'de Ülke Yönetimi, Derleyen: Tülay Ercoşkun, İmge Kitabevi, Ankara 2007, s. 65.

Ancak bu görüşler; Tuna Vilayeti'nin oluşumunda üç eyaletin birleştirilmiş olması olgusu ile çelişmektedir. Zaten vilayet sistemine geçişin fikir babası Fuad Paşa, eyaletleri büyütülmesini ve başına "muktedir" valiler getirilmesini savunmuş, Tuna Vilayeti uygulaması bu şekilde ortaya çıkmıştır. Diğer vilayetler de yine birkaç eyaletin birleştirilmesiyle oluşturulacaktır. Bkz., Yaman, "agm”, s. 1491-1498.

7 “1871 İdare-i Umumiye-i Vilayat Nizamnamesi”, Maliye Bakanlığı Bütçe ve Mali Kontrol Genel Müdürlüğü, age., s. 26-30. 
eyaletlerin birleştirilerek daha geniş mülkî daireler oluşturulması ve bu geniş mülkî dairelere "muktedir" valilerin atanmasıyla sik1 merkeziyetçilikten uzaklaşılabilir ve sık1 merkeziyetçiliğin neden olduğu sıkıntıların üstesinden gelinebilirdi. Böyle bir değişim; vilayetlerin küçük işleri ile ilgili kararlar alabilme noktasında valilerin önünü açar; böylece yalnızca önemli işlerden merkezi idareye başvurulmasını ve işlerin daha seri bir şekilde yürütülebilmesini sağlardı. ${ }^{8}$

Açıkça anlaşılacağı üzere bu tarihlerde; valilerin yetkilerinin arttırılması, merkeziyetçilikten uzaklaşmayı sağlayacak bir araç, geniş vilayet sistemi ise bu aracın kullanılacağı en uygun mülkî daire olarak düşünülmekteydi. ${ }^{9}$ Ancak zaman içinde bu düşünce geçerliliğini yitirecekti. Nitekim II. Meşrutiyet Dönemi’ne gelindiğinde, dönemin aydınları ve siyasileri arasındaki en temel tartışma konularından biri vilayetlerin tüzel kişiliğinin kabul edilerek, valilere değil, vilayet meclislerine yetki ve sorumluluk vermek; ${ }^{10}$ diğeri ise mülkî idare dairelerinin sınırlarını daraltmaktı. ${ }^{11}$ Zira geniş vilayetlere dayalı mülkî taksimatın taşrada idarî işlerin ciddi şekilde aksamasına neden olduğu düşünülmekteydi.

Bu dönemde hükümet de bu meselelerin çözümü ile ilgili çalışmalar yürütmekteydi. 1909 yılında başlatılan bu çalışmalar, 1913 yılında İdare-i Umumiye-i Vilayat Kanun-1 Muvakkatı'nın çıarılmasıyla sonuçlandı. Kanunun kabulüyle birlikte bir yandan vilayetlere tüzel kişilik tanınırken, diğer taraftan da vilayet meclislerine, vilayeti ilgilendiren işlerde karar alma ve uygulama yetkileri verildi. Zira kanunun hazırlayıcılarına göre, merkeziyetçilik istibdat yönetimlerine has bir uygulamaydı ve bu uygulamayı bertaraf etmenin temel yolu ise mahallî idarelere yetki vermekten geçiyordu. ${ }^{12}$ Yapılan değişiklik Osmanlı idare tarihinde tam anlamıla bir devrimdi.

Bu dönemde ele alınan diğer önemli sorun olan mülkî taksimatın yeniden yapılandırılması ise çözümsüz kaldı. Zira hükümet, Meclise sunmayı vaat ettiği, mülkî taksimatın yeniden yapılandırılması hakkındaki projeyi tamamlayamamıştı. ${ }^{13} \mathrm{Bu}$ sebeple ülkedeki mevcut mülkî taksimat, 1913 İdare-i Umumiye-i Vilayat Kanun-1 Muvakkatı’nda da aynen kabul edildi. ${ }^{14}$

İdare-i Umumiye-i Vilayat Kanun-1 Muvakkatı'nın çıkarılmasından kısa bir süre sonra ise Osmanlı Devleti I. Dünya Savaşı'na girdi. Böylece taşra idarelerinde işlerin aksamasına neden olan bu sorunlu mülkî taksimat, Türkiye Devleti’ne devretti.

\footnotetext{
${ }^{8}$ Talat Mümtaz Yaman, “agm”, s. 1471. Behlülgil, age., s. 138.

9 Aslında "vali” de merkezi yönetim örgütünün bir memurudur. Günümüzün idare anlayışına göre, valilerin yetkilerinin arttırılması "merkeziyetçiliği”" azaltan değil, arttıran bir uygulamadır. Merkeziyetçiliği azaltacak anahtar, Valilere değil, "vilayet idarelerine" yetki vermektir. Ancak bu tarihlerde, tüzel kişiliğe sahip bir vilayet teşkilatı olmadığı gibi; vilayete ait bir takım işlerde karar alma ve uygulama yetkisine sahip Vilayet Genel Meclisleri de yoktur. Dolayısıyla, valilerin yetkilerinin arttırılması merkeziyetçiliği azaltacak bir gelişme olarak değerlendirilmektedir.

${ }^{10}$ Ayrıntılı bilgi için bkz., Murat Burgaç, "Osmanlı Devleti'nde Adem-i Merkeziyetçilik Tartışmaları (1876-1913)", Amme İdaresi Dergisi, C.51, S.2, Haziran 2018, s.144-176.

${ }^{11}$ Bu konuda ayrıntılı bilgi için bkz., Nuray E. Keskin, "II. Meşrutiyet’te Yeni Düzen Arayışı", 18. Yüzyıldan 21. Yüzyıla Kaтu Yönetiminde Reform, TODAİE, Ankara 2009, s. 225-236.

${ }^{12}$ Bkz., "Encümen-i Mahsus Tarafindan Tadilen Tanzim Olunan İdare-i Vilayet Kanunu Layihasıla Esbab-1 Mucibe Mazbatası", Meclis-i Mebusan Levayih ve Tekalif-i Kanuniye ve Encümen Mazbataları (MMLTKEM), Sene: 1326-1327, Sira No: 26, TBMM Basımevi, Ankara 1992, s. 56-58.

${ }^{13}$ Agb., s. 64.

14 “ذ̇dare-i Umumiye-i Vilayat Kanun-1 Muvakkatı”, Maliye Bakanlığı Bütçe ve Mali Kontrol Genel Müdürlüğü, age., s. 270.
} 


\section{TBMM'nin Açılması ve Mülkî Taksimatın Yeniden Düzenlenmesi}

Dünya Savaşı yenilgisi, Osmanlı Devleti'nin sonunu getirirken, yenilgi sonrası başlayan işgallere karşı Mustafa Kemal Paşa'nın öncülüğünde başlatılan Milli Mücadele, yeni bir devletin doğmasına zemin hazırladı. Nitekim 23 Nisan 1920'de Ankara'da Büyük Millet Meclisi'nin açılmasıyla Anadolu'da yeni ve ulusal bir devletin temelleri atıldı. Elbette ki Meclisin en önemli görevi ulusal bağımsızlık savaşını yürütmek, yönetmek ve başarıya ulaştırmaktı. Ancak yeni bir devletin kuruluş sürecinin de bağımsızlık mücadelesi ile eşzamanlı olarak yürütüldüğü bu dönemde, Meclis; idarede görülen sıkıntıları çözebilmek ve halkın ihtiyaçlarına uygun, halkçı bir idare kurabilmek konusuna da büyük bir mesai ayırmaktayd1. Zira Meclisteki hakim düşünceye göre; her ne kadar vatanı kurtarmak için toplanılmışsa da "memleketi yaşatmaya çalışmak ve hastalık neredeyse onu bulmak ve yok edinceye kadar devrim yapmak" da Meclisin göreviydi. Ülkedeki en önemli hastalık ise "sui idare hastalığıydı. "15 Dolayısıyla ilk devrim, idarî alanda yapılmalıydı.

Meclisteki vekillerin pek çoğu, sui idare hastalı̆̆ının üstesinden gelmenin yolunun, merkeziyetçiliği azaltmak ve vilayet idarelerinin yetkilerini arttırmaktan geçtiğini düşünüyordu. 20 Ocak 1921 tarihinde kabul edilen Teşkilat-1 Esasiye Kanunu, yeni devletin kurucularının bu düşüncelerinin uygulamaya girmesini sağladı. Nitekim kanunun 11 ila 14. maddeleri ile vilayetin tüzel kişiliği tanınıyor ve vilayet meclislerine mahallerini ilgilendiren işleri yürütmekle ilgili geniş yetkiler veriliyordu. ${ }^{16}$ Gerek vilayet ile ilgili maddeler ve gerekse bu maddelerin görüşülmesi sırasında yapılan konuşmalar, I. Meclisin merkeziyetçiliğe oldukça mesafeli hatta karşı bir tutum içinde olduğunu açıkça göstermekteydi. Bunun temel gerekçesi ise halkın yönetime katılımını arttırma isteğiydi. Bu tutum, II. Meşrutiyet Dönemi'nden beridir devam eden anti-merkeziyetçi idare anlayışının devamı ettiğini göstermekteydi. Nitekim dönemin Dahiliye Encümeni Reisi Vehbi Bey, bu konuda şöyle diyordu:

"Bunun manası, memleketin asıl sakinleriyle idaresi demektir...Bir memlekette idarî ve mahallî teşkilat olmadıkça o memlekette meşrutiyet var demek de yalandır, hayaldir. ${ }^{17,}$,

Teşkilat-ı Esasiye Kanunu, vilayet idarelerini yeniden yapılandırmakla kalmadı aynı zamanda ülkede mülkî taksimat alanında yaşanan soruna da çözüm getirdi. Yukarıda açıklandığı üzere bu dönemde mülkî taksimat alanında yaşanan sorunun kaynağında geniş vilayetler yatmaktaydı. Zira dönemin ulaşım ve iletişim araçlarının yetersizliği, bu geniş vilayetlerde hızlı işleyen bir idare mekanizması kurmayı engellemekte ayrıca "kaza" ile

\footnotetext{
${ }^{15}$ Teşkilat-1 Esasiye Kanunu Tasarısının Özel Encümeni Mazbata Muharriri İsmail Suphi Bey, Mecliste kanun ile ilgili yaptığı açıklamada ülkenin en önemli sorununun idarenin kötü yönetilmesi olduğunu şu sözlerle ifade etmekteydi: "Biliyorsunuz ki; bu memleketin öteden beri bir hastalı̆̆ vardır. Bu hastalık sui idare hastalığıdır. Memleket devri inhitata başladı̆̆ından İtibaren sui idare anbean artmış ve eksilmemiştir...Biliyorsunuz ki; devr-i meşrutiyette vakit vakit teşebbüsler oldu, idare-i vilayat kanunu ilân edildi...Halkın ihtiyacını düşünmek, yukarı tabakanın aşağı tabakaya doğru inerek, halkı anlamak, dinlemek, birlikte yükseltmek emelleri baş gösterdi. Fakat bunlar ihtilâl gulguleleri ve harp topları arasına karıştı, gitti, hiç bir netice hasıl edemedi... Memleketin illetlerinde, dahili sui idarenin büyük bir tesiri vardır...Islah ve inkılap zaruretini anladık ve yeni bir idare kurmak için bir takım istihzarat yapmağa başladık. Binaenaleyh bugün Meclisi Aliniz müdafaa için toplanmış olmakla beraber, bu memleketi, bu milleti yaşatmak için en iyi esas nerede ise onu bulmağa ve ledehacce her şeyden inkalâp yapmağa her şey ve her şey yapmağa karar vermiştir. İşte Hükümetin halkçılık programı namı altında Meclis-i Alinize sevkettiği program bu fikirlerin mahsulüdür.” Türkiye Büyük Millet Meclisi Zabıt Ceridesi (TBMMZC), Devre (D).1, C.5, TBMM Basımevi, Ankara 1981, s. 407-409.

${ }^{16}$ Teşkilat-1 Esasiye Kanununun tam metni için bkz., Suna Kili-Şeref Gözübüyük, Türk Anayasa Metinleri, Türkiye İş Bankası Yayınları, İstanbul 2000, s. 100-102.

${ }^{17}$ TBMMZC, D.1, C.6, TBMM Matbaas1, Ankara 1943, s. 359.
} 
"vilayet" arasında tüzel kişiliğe sahip olmayan "liva" teşkilatının bulunması ${ }^{18}$ halkın idare ile ilgili işlerinin uzamasına ve aksamasına sebebiyet vermekteydi. ${ }^{19}$

Birkaç livadan oluşan geniş vilayet sisteminin yarattı̆̆ı bir diğer sıkıntı ise, malî kaynakların eşit dağılımının sağlanamamasıydı. Bu sistemde, vilayete bağlı tüm livaların mahallî gelirleri, vilayet merkezi olan livada toplanıyor ve buradan idare ediliyordu. $\mathrm{Bu}$ durumda vilayet merkezi olan liva lehine ve o vilayete bağlı diğer livaların aleyhine bir durum ortaya çıkıyordu. ${ }^{20}$

Geniş vilayet sisteminin yarattığı bu sıkıntılar II. Meşrutiyet devrinde fark edilmiş ve fakat çözülememişti. Hal böyle olunca vilayetlere "mülhak" (bağlı) olan bazı livalara, "müstakil" (bağımsız) unvanı verilerek doğrudan merkeze bağlanması gibi geçici ve kısmî bir çözüm yoluna gidilmişti. ${ }^{21}$ Nitekim bu dönemde ülkede; 15 vilayet, 25 'i müstakil, 34'ü mülhak olmak üzere 59 liva, 299 kaza ve 679 nahiye vardı. ${ }^{22}$

Yeni devletin kurucuları, Meşrutiyet döneminden beri tartışılagelen bu sorunu; liva teşkilatını tümden kaldırıp, tüm livalara vilayet unvanı vererek radikal biçimde çözme yoluna gittiler ve Teşkilat-1 Esasiye Kanunu'nun 10. maddesiyle; Türkiye'nin; “coğrafi vaziyet ve iktisadi münasebet noktai nazarindan vilayetlere, vilayetler kazalara münkasem olup kazalar da nahiyelerden terekküp” edeceği hükmünü kabul ettiler. Bu maddeyle birlikte; Türkiye'deki mülkî idare bölümleri; vilayet - kaza ve nahiye olmak üzere üç kademeye indirilmiş oldu. Ülkedeki mevcut 59 livanın tamamı vilayet olarak kabul edildi ve Türkiye'deki vilayet sayısı 74 'e yükseldi. ${ }^{23}$

Liva teşkilatının kaldırılarak, her livanın bir vilayet kabul edilmesiyle; ülkenin mülkî taksimatındaki en büyük idarî birim olan vilayetlerin, sınırları önemli ölçüde daraldı. Önceden ortalama üç livanın birleşimiyle oluşan vilayetler, artık yalnızca tek livalık bir fiziki alanda örgütleneceklerdi.

Yapılan değişiklikler sayesinde; taşradaki idarî sistemin daha hızlı bir şekilde işleyebileceği ve halkın idare ile ilgili iş ve işlemlerinin "mahallînde" ve seri bir şekilde halledilebileceği düşünülmekteydi. Ayrıca artık her liva, kendi mahallî gelirini kendisi kullanacağından, kaynakların dağılımındaki eşitsizlik de ortadan kaldırılabilecekti. Ancak bu değişikliklerin iki temel sıkıntı yaratabileceği öngörülmüştü.

Bunlardan ilki; vilayet meclislerine verilen geniş yetkilerin, ülkenin idarî yapısındaki birliğe zarar verebileceği endişesiydi. Daha açık bir ifade ile federatif bir yapıya doğru bir gidiş yaşanmasından kaygı duyulmaktaydı. Zira her ne kadar mülkî dairelerin daraltılması daha etkin bir merkezi denetimin önünü açmış olsa da, 1921 Anayasası'yla vilayet idarelerine o güne kadar sahip olmadıkları oldukça geniş yetkiler verilmişti ve bu yetkilerin merkez adına,

\footnotetext{
${ }^{18}$ II. Meşrutiyet devrinde vilayetlere tüzel kişilik tanınmakla birlikte livalara tanınmamıştı.

${ }^{19}$ Başbakanlık Cumhuriyet Arşivi (BCA), Cumhuriyet Halk Partisi Kataloğu (CHPK), "Dahiliye Vekaletinin CHP Büyük Kurultayına Umumi İşler ile İlgili Sunduğu Rapor”, Fon Kodu (FK): 490.1.0.0, Yer No: 212.840.1, Tarih: 24.02.1938.

20 "Umumi Müfettişlik Teşkiline Dair Kanun Layihası Hakkında Dahiliye Encümeni Mazbatası", TBMMZC, D.2, C.33, TBMM Matbaası, Ankara yy. yok, s. 683.

${ }^{21}$ Göreli, age., s. 59.

22 "İller İdaresi Genel Müdürlüğünün Mülkî Taksimat Hakkındaki Raporu”, İçişleri Bakanlığı, I. İdareciler Kongresi, (20 Ocak 1947-31 Ocak 1947), Akın Matbaas1, Ankara 1947, s. 192.

23 "Mülkî Taksimat Hakkında Mülkî Taksimat ve İçişleri Bakanlığı Teşkilat Kanunu Komisyonunun Raporu" İçişleri Bakanlığı, age., s. 467.
} 
yakından ve sıkı denetime tutulması; idarede ayrılıkçı akımların ortaya çıkması olasılı̆̆ına karşı önlem alınması gerekiyordu. ${ }^{24}$

İkincisi ise; kurulacak olan vilayetlerin son derece küçük ve az nüfuslu olmaları dolayısıyla yeterli malî kaynaklara sahip olamayacakları ve bu sebeple de vilayet meclislerinin sorumluluğuna bırakılan mahallî işleri gerçekleştiremeyecekleri endişesiydi.

Yeni devletin kurucuları; ortaya çıkması muhtemel bu iki sıkıntının üstesinden gelebilmek için, Teşkilat-1 Esasiye Kanununda, ülkenin idarî sisteminde o güne kadar olmayan bir teşkilatın kurulmasını hükme bağlamışlar ve anayasanın 22. maddesiyle "vilayetler [in] iktisadi ve içtimai münasebetleri itibariyle birleştirilerek umumi müfettişlik kıtaları vücuda" getirileceğini kabul etmişlerdi. ${ }^{25}$

Nitekim Teşkilat-1 Esasiye Kanunu görüşmelerinde; İsmail Suphi Bey, "Memleketin vahdetini muhafaza etmek için de bir şey düşündük... İktisadi, coğrafi münasebetleri itibartyla

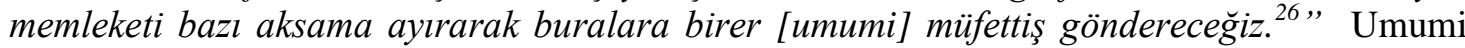
müfettişler; "Devletin umumi vezaifiyle mahallî vezaifin cereyan ve tatbikatın murakabe [edecekler] ve böylece vasi bir adem-i merkeziyetle idare olunan memleket aksaminin merkeze slkı bir surette irtibatı ile Devlet ve Hükümet makinesinin muntazaman işlemesi[ni] ${ }^{27}$ " sağlayacaklar diyerek müfettişliğin kurulmasındaki ilk nedeni açık bir şekilde dile getirmişti.

Dahiliye Vekaleti Müsteşarı Hamid Bey ise; Teşkilat-1 Esasiye Kanunu ile ülkenin küçük vilayetlere taksim edildiğini, bu nedenle de düşük bütçeli vilayetler ortaya çıktığını belirtiyor ve "25 bin lira varidat-ı hususiyesi olan bir liva[nın] kendisine kanunun tevdi ettiği vezaifin hiç birini göreme[yeceğini] ${ }^{28 " ~ v u r g u l u y o r d u . ~} \mathrm{Bu}$ sebeple de iktisadi ve içtimai durumları benzerlik gösteren vilayetleri bir "mıntıka" altında toplayarak, bunların mali kaynaklarını bir araya getirmek ve ortak işlerini tek bir elden yapmalarını sağlamak amacıyla Umumi Müfettişlikler kurmak istediklerini ifade ediyordu. Bu açıdan umumi müfettişlikler bir bakıma “umumi vilayetler" $\mathrm{di}^{29}$ ve tam olarak küçük vilayet sisteminin yaratması muhtemel sıkıntılarına çözüm yolu olarak düşünülmektelerdi.

\section{Yeni Mülkî Taksimatın Yarattığı Sıkıntılar}

1921 Anayasası'nın kabulünden kısa bir süre sonra, Umumi Müfettişlik Hakkındaki Kanun Tasarısı Hükümet tarafından Meclise sunuldu, fakat yasalaşamad $1 .{ }^{30} \mathrm{Bu}$ ise; 1921 Anayasası'yla vilayet idareleri ve mülkî taksimat konusunda yapılan değişikliklerden kaynaklanabileceği öngörülen sıkıntıların kaçınılmaz bir şekilde gündeme gelmesine neden oldu. Ancak hemen belirtmek gerekir ki ortaya çıkan bu sıkıntılar; vilayetlere verilen yetkilerin "ülke vahdet”"ine zarar vermesi noktasında değil, mülkî taksimatın değiştirilerek küçük vilayet sistemine geçiş noktasındaydı. Bu nedenle de kısa bir süre sonra Mecliste, ülkedeki mülkî taksimatın yolunda olmadığ 1 ve değiştirilmesi gerektiği fikirleri tartışılmaya başlandı. Nitekim 11 Nisan 1922'de Meclisin gizli oturumlarında Maliye Vekili Hasan Bey; ülkedeki mevcut savaş halinden dolayı bütçenin büyük kısmının orduya ayrıldığını, gelir kaynaklarının son

\footnotetext{
${ }^{24}$ Gerçi vilayetlerde merkez adına ve merkezi temsilen görev yapacak bir vali bulunacaktı. Ancak vilayet idarelerine bu kadar geniş yetkiler verildiği bir sistemde sadece valinin yapacağı bir merkezi denetim yeterli görülmemekteydi.

${ }^{25}$ Kili-Gözübüyük, age., s.102.

${ }^{26}$ TBMMZC, D.1, C.5, , s. 412.

${ }^{27}$ TBMMZC, D.1, C.5, s. 414.

${ }^{28}$ TBMMZC, D.1, C.13, TBMM Matbaası, Ankara 1958, s. 175.

${ }^{29}$ TBMMZC, D.1, C. 13 , s. $175,176$.

${ }^{30}$ Umumi Müfettişlik hakkındaki kanun tasarısı ve görüşmeler için bkz., TBMMZC, D.1, C.13, s. 168-182.
} 
derece azaldığını ve malî durumun çok fena bir vaziyette olduğunu açıkladıktan sonra vilayet idarelerine değiniyor ve şöyle diyordu:

"Bendenizin kanaatime göre 20-30 bin lira varidatı olan bir mahallîn 50 - 80 bin nüfusla vilayet olmasına ve vilayet teşkilatı ihtiva etmesine Maliye Vekilinin aklı ermez. Binaenaleyh, bütün teşkilat-l devletin yeniden tanzim edilmesi ve evvel beevvel teşkilat-ı mülkîyeden başlanması lazım gelir...Mahallî hidemat-ı umuru temin edecek hiç bir mahallîmiz yoktur. Menabi bulmanın da imkan ve ihtimali yoktur. Yani [bugün] hiç bir vilayet bir darülmuallimine bile nail olamaz. ${ }^{31}$,

Büyük zaferin hemen öncesinde ise bu kez Refet Paşa, bu konuyu gündeme getirerek şunları söylüyordu:

"Benim bu memlekete yaptı̆̆ım fenalık şudur ki .... her sancağı müstakil yapmak prensibini takip ettim. ${ }^{32}$ Maksadım evvela her sancă̆l müstakil yaptıktan sonra, makul bir tarzda bunları birleştirerek yeniden büyük vilâyetler tanzim etmek idi. Başını yaptık, fakat nihayetini getiremedik. ${ }^{33}$,"

Hal böyle olunca; mülkî taksimatın yeniden düzenlenmesi meselesi, Lozan Antlaşması'nın imzalanmasıyla bağımsız bir devlet olarak tarih sahnesindeki yerini alan Türkiye'nin önünde çözmesi gereken en temel meselelerden biri olarak belirdi. Nitekim 5 Eylül 1923'te Mecliste okunan İcra Vekilleri Heyeti Programında; ülkedeki mülkî taksimatın bilimsel esaslara göre belirlenmediği bu nedenle de pek çok sıkıntının ortaya çıktığı vurgulanmakta ve yakın zamanda bu konuda bir kanun tasarısının Meclise sunulacağı belirtilmekteydi. ${ }^{34}$

\section{Türkiye Cumhuriyeti Dönemi}

29 Ekim 1923’te Cumhuriyet ilan edilerek yeni devlet rejimini belirlediğinde, mülkî taksimatın "ilmî bir şekilde" düzenlenmemiş olmasının yarattığı sıkıntılar gündemdeki yerini korumaktaydı. Bu sikıntıların üstesinden gelebilmek için; Kozan, Gelibolu, Tekirdağ, Kırklareli, Ergani, Hakkari, Mersin gibi bazı küçük vilayetler, "mülhak vilayet" adı altında, yakınlarındaki büyük vilayetlere bağlı olarak yönetilmekteydi. ${ }^{35}$ Doğal olarak bu durum, vilayetlerin vilayetlere bağlanması gibi anormal ve aslında anayasaya da aykırı bir durum yaratmaktaydı 1923 yılı Aralık ayında Mersin Milletvekilleri Niyazi ve Besim beyler tarafından verilen takrirlerle bu mesele Meclis gündemine taşındı.

Takrirlerde; 1921 Anayasası'na göre liva teşkilatının kaldırılarak her livaya vilayet unvanı verildiği halde, Mersin'in Adana Vilayeti'ne bağlı olarak idare edilmekte olduğu belirtiliyor, bu durumun Mersin halkına yapılmış bir haksızlık olduğunun altı çiziliyor ve anayasa hükümlerinin Mersin için niçin uygulanmadığı, ne zaman uygulanacağı konularını Dahiliye Vekilinin cevaplaması isteniyordu. ${ }^{36}$

Böylece Mecliste ciddi bir tartışma başladı. Görüşmelerde söz alan Dahiliye Vekili Ferid Bey'in konuyla ilgili olarak yaptığı açıklamalar; yaşanan sıkıntıları gözler önüne sermekteydi. Şöyle diyordu Vekil Bey:

“...Malûmuâliniz, vilâyetlerimizi ve livalarımızı müstakil yapmak hususunda bir cereyan bulunduğu esnada, bütün livalarımız istiklâle doğru sevk edilmiştir. Fakat... idare-i hususiye nokta-i nazarından bu tarzda ufaltılmış bulunan vilâyetlerimizin memleketin mahallî imarı cihetinden faaliyette bulunmadiğ tarafindan meşhuttur. Hattâ o kadar ki, İdare-i Hususiye-i Vilâyat Kanununun vermiş olduğu salâhiyetler, bu

${ }^{31}$ Türkiye Büyük Millet Meclisi Gizli Celse Zabıtları (TBMMGCZ), D.1, C.3, Türkiye İş Bankası Kültür Yayınları, Ankara 1985, s. 204-205.

${ }^{32}$ Refet Paşa, Dahiliye Vekilliği yaptığı döneme atıfta bulunarak konuşmaktadır.

${ }^{33}$ TBMMGCZ, D.1, C.3, s. 666.

${ }^{34}$ İcra Vekilleri Heyeti Programı (05.09.1923), TBMMZC, D.2, C.1, TBMM Matbaası, Ankara 1961, s. 422.

${ }^{35}$ TBMMZC, D.2, C.4, TBMM Matbaas1, Ankara 1968, s. 112.

${ }^{36}$ TBMMZC, D.2, C.4, s. 111. 
dairede mahdut bulunan vilâyetlerin varidatı ile idare edilemediğinden dolayı bilâkis rücu hâsıl olmuş, memleketimizde mahallî idarelerin inkişafi, idare-i hususiyelerin tevsii, tefriki mesai gayemiz olduğu halde maalesef tatbikatta muvaffak olunamamıştır. Vaktiyle idare-i hususiyelere vermiş olduğumuz birtakım mektep ve saireyi yeniden umumi bütçeye ilhaka mecbur olmuşuzdur. Bu neyi gösterir efendiler? Bu da muhtelif dairelerde bazı idarî ıslahatın vücup ve lüzumunu gösterir...Filhakika bu teşebbüs de başlamıştır. ${ }^{37,}$

Dahiliye Vekilinin yaptığı konuşma, küçük ve kaynakları yetersiz vilayetlerin yarattığı sıkıntıları gösterdiği gibi; 1921 Anayasası'yla vilayet meclislerine mahallî işlerle ilgili verilen idarî özerklikten geriye doğru, "merkeziyetçiliğe” doğru bir gidiş yaşandığını da göstermekteydi. Bu ise yeni devletin kurucularının hiç de istediği bir durum değildi. Zira onlar; ülkenin içinde bulunduğu felaketlerin en temel sebebinin "merkeziyetçilik" olduğunu düşünüyor; "halkçı" bir idare kurmanın temel yolunun, vilayet idarelerinin yetkilerini arttırmaktan geçtiğine inanıyorlard ${ }^{38}{ }^{38}$ Bundan dolayıdır $k i$; "vezaif-i mahallîye ve hidematumran perveriyi bizzat halkın dest-i himmet ve kudretine vermek suretiyle (Halka doğru gitmek) ve tabir-i diğerle (halk idaresi tesis etmek) hususundaki niyat ve amal-i islahat küsteranesini ahiren tanzim ve kabul etmiş olduğu (Teşkilat-ı Esasiye Kanunu) ile izhar ve ilan eylemiş[lerdi]. ${ }^{39 "}$ Fakat mülkî taksimatta yaşanan sorun çözülemediği takdirde merkeziyetçiliğe doğru gidiş sürecinin devam etmesi kaçınılmaz gözüküyordu ve nitekim öyle de olacaktı.

Yaşanan sıkıntıların ortaya çıkardığı reel durum, "mülhak vilayetlerin" milletvekilleri tarafından ise pek de önemsenmemekteydi. Nitekim 1924 yılı Dahiliye Vekaleti bütçesi görüşmelerinde Ergani milletvekili Kazım Vehbi Bey aynı konuyu tekrar gündeme getirdi ve 10 vilayetin mülhak olarak idare edilmekte olmasının anayasaya aykırı bir durum olduğunu ifade ederek Hükümeti anayasayı çiğnemekle itham etti. Kazım Vehbi Bey; "Heyet-i Celileniz teşkilat-ı esasiye kanununun nazımı olduğu kadar murakıbıdır da...Bu vaziyeti izale etmenizi istirham ederim." sözleriyle hükümeti Meclise şikayet etti ve yanlışlığın düzeltilmesini istedi. ${ }^{40}$ Mülhak vilayetlerin milletvekillerinin hep birlikte Dahiliye Vekiline yüklenmeleri ve başka bazı vilayetlerin milletvekillerinin de onlara destek vermeleri Ferid Bey'i çok zor durumda bıraktı. Vekil beyin, bu küçük vilayetlerin nüfus ve gelir itibariyle müstakil vilayet olmaya elverişli olmadıkları yönündeki açıklamaları pek bir sonuç vermedi. Nihayet Üsküdar ve Beyoğlu hariç olmak üzere kalan sekiz vilayetin müstakilen idare edilmeleri kabul edildi. ${ }^{41}$

1924 Bütçe görüşmelerinde mülkî taksimat konusunda bir başka önemli gelişme daha yaşandı ve "teşkilat-ı hazıranın, nüfus ve varidatına, içtimai, coğrafi vaziyetlere ve iktisadi cereyanlara göre tanzim ve ıslahı, müemmen bir teşkilat-ı mülkîye kanununun bilihzar 1341 bütçesiyle birlikte Meclise takdimi" konusunda hükümete yetki verildi. ${ }^{42}$

1924 Bütçesinin kabulünden hemen sonra ise Türkiye Cumhuriyeti Devleti, yeni bir anayasa çıkardı. Altı fasıl ve 105 maddeden oluşan 1924 Anayasası' nın kabulüyle yeni rejimin ve yeni devletin oturacağ ülkedeki vilayet idareleri de yeniden yapılandırdı. ${ }^{43}$

\footnotetext{
${ }^{37}$ TBMMZC, D.2, C.4, s. 114-116.

${ }^{38}$ Meclisteki hakim olan bu düşünce ile ilgili örnekler için bkz., Teşkilat-1 Esasiye Kanunu Layihası Görüşmeleri, TBMMZC, D.1, C.5, s. 407-418.

39 "İdare-i Nevahi Kanununun Esbab-1 Mucibe Layihası", TBMMZC, D.1, C.12, Sira No: 5, TBMM Matbaas1, Ankara 1958, s. 6.

${ }^{40}$ TBMMZC, D.2, C.7, TBMM Matbaası, Ankara 1970, s. 157.

${ }^{41}$ Görüşmeler için bkz., TBMMZC, D.2, C.7, s.157-198.

${ }^{42}$ TBMMZC, D.2, C.7, Sira No: 11, s. 1.

431924 Teşkilat-1 Esasiye Kanununun tam metni için bkz., Kili-Gözübüyük, a.g.e., s. 120-141.
} 
89. maddeye göre Türkiye; "coğrafi vaziyet ve iktisadi münasebet noktai nazarından vilayetlere, vilayetler kazalara, kazalar nahiyelere münkasemdi ve nahiyeler de kasaba ve köylerden terekküb edecekti." Bu maddeyle Cumhuriyet rejimi, ülkenin mülkî taksimatını açıklamış oluyordu. Bu taksimatta "vilayet" en büyük "cüz'ü tam" olarak kabul edilmekteydi. Bu açıdan 1921 Anayasası'nın getirdiği hükümle arasında bir farklılık yoktu.

Anayasanın 90. maddesiyle; vilayetlerin tüzel kişiliği tanınıyor; 91. Maddesiyle de vilayetlerin yetki genişliği ve görev ayrımı ilkelerine göre idare edileceği kabul ediliyordu. Dolayısıyla Cumhuriyet idarecilerinin vilayet idareleri alanında; 1913 İdare-i Umumiye-i Vilayat Kanun-1 Muvakkatı ve 1921 Anayasası çizgisini devam ettirdiği görülmekteydi. Ancak bu tarz bir idarenin, vilayetlerde, hangi organlar aracıllğıyla yürütüleceği açıklanmamıştı. 1921 Anayasası'nda mevcut olan “vilayet meclisleri”nin oluşumunu ve bu meclislerin yetki ve sorumluluklarını açıklayan maddeler, 1924 Anayasası'nda yoktu.

Acaba Cumhuriyet yöneticileri vilayet idarelerine verilen özerkliği daraltmak niyetindeler miydi? Gerçi Anayasa Encümeni Mazbata Muharriri Celal Nuri Bey, anayasada; vilayetlerin tüzel kişiliğinin tanınarak temel çerçevenin çizilmiş olduğunu, vilayet meclislerinin de bu çerçeve kapsamına girdiğini, ayrı bir hükme gerek olmadığını söyleyerek; vilayet idareleri ile ilgili kapsamlı düzenlemelerin de anayasayla değil, yakında çıkarılacak olan İdare-i Vilayet Kanunuyla yapılacağını vurgulamaktayd $1 .{ }^{44}$ Ancak bu konudaki gelişmeler gidişatın pek de öyle olmayacağını gösterecekti.

1924 Anayasası'nın vilayet idareleri alanında getirdiği önemli bir değişiklik de “Umumi Müfettişlik Teşkilatı" konusundaydı. Nitekim Anayasada Umumi Müfettişlik Teşkilatına yer verilmemiş; böylece, 1921 Anayasası'yla uygulamaya konulan küçük vilayet sisteminin yaratacağı bir takım sıkıntılara bir çözüm olarak düşünülen, Umumi Müfettişlik Teşkilatının yasal dayanağı kaldırılmıştı. Bu nedenle de mülkî taksimat alanında yaşanan sıkıntılar ve sıkıntıları çözebilmek için çalışmalar, 1924 Anayasası'nın kabulünden sonra da devam etti.

\section{Taksimat-ı Mülkîye Kanunu'nun Kabulü}

Hükümet, yeni bir mülkî taksimat kanunu hazırlamakla ilgili yetki almış olmasına ve 1924 Anayasası görüşmelerinde yakın zamanda vilayet idarelerini düzenleyecek yeni bir kanun çıkarılacağı ifade edilmiş olmasına rağmen konuyla ilgili çalışmalara başlamamıştı. Nitekim 1925 y1l Dahiliye Vekaleti bütçesi görüşmelerinde Karesi milletvekili Vehbi Bey, hükümeti şu sözlerle eleştirmekteydi:

"Teşkilat-ı Mülkîye, geçen sene de evvelki sene de Meclis burada açıldıktan beri ve daha evvelden beri temcid pilavı gibi mütemadiyen usitıliyor...Evvelce 23 vilayet iken şimdi $72^{45}$ oldu. Binaenaleyh bugünkü idare-i umumiyenin, bugünkü idare-i hususiyenin, belediyenin bu şekilde idame ve muhafazası kâbil değildir...[Bu vilayetler] ne idare-i mahallîye teşkilatında muvaffak olabilirler, ne de idare-i umumiyeleri şamil bir manzara sahibi olabilirler... Biran evvel idare teşkilatını tanzim etmek zarureti vardır. ${ }^{46,}$

Meclisteki bu görüşmelerin hemen ertesinde, Doğu Anadolu bölgesinde Şeyh Said isyanının patlak vermesi, ülkedeki mülkî taksimatın yeniden düzenlenmesi sürecini hızlandırdı. Nitekim isyandan sonra, Türkiye'deki vilayetlerin; coğrafi, iktisadi ve sosyal durumlarını incelemek ve konuyla ilgili raporlar hazırlamak amacıyla 15 heyet oluşturulması

\footnotetext{
${ }^{44}$ TBMMZC, D.2, C.8, TBMM Matbaas1, Ankara 1975, s. 915

${ }^{45}$ Aslında bu tarihte ülkede 74 vilayet vardı. Muhtemelen Üsküdar ve Beyoğlu vilayetleri göz ardı ediliyor -Zira fiilen İstanbul'a bağlı olarak yönetiliyorlardı ve Mecliste bunların vilayet olarak kabul edilemeyeceği görüşü hakimdi.- ve bu yüzden 72 vilayet olduğu dile getiriliyordu.

${ }^{46}$ TBMMZC, D.2, C.14, TBMM Matbaas1, Ankara 1976, s. 35.
} 
kararlaştırıld1. ${ }^{47} \mathrm{Bu}$ incelemeler yapılırken hangi noktaların göz önünde bulundurulacağ 1 hakkında bir talimatname hazırlamak ve heyetlerin hazırlayacakları raporları inceleyerek, ülkenin idarî ve mülkî teşkilatında yapılması gerekenleri üst raporla Meclise sunmak için de bir "Merkezi Heyet" kuruldu. Merkezi Heyet; Erkan-1 Harbiye Riyaseti'nden, Müdafaa-i Milliye, Nafia, Maliye, Sıhhiye, Adliye Vekaletlerinden tayin edilen kişiler ile dahiliye müdürlerinden oluşuyordu. ${ }^{48}$ Ekim 1925 'te, heyetler raporlarını Merkezi Heyet'e sunmuş ve Merkezi Heyet de bu raporları inceleyerek kendi raporunu hazırlamıştı. ${ }^{49} \mathrm{Bu}$ raporların Dahiliye Vekaletince incelenmesinin ardından, Türkiye'nin mülkî taksimatında önemli değişiklikler meydana getirecek olan bir proje hazırlandı. Hazırlanan proje, "Teşkilat-ı Mülkîye Kanun Layihası", adıyla ve layihanın gerekçesini oluşturan bir raporla birlikte, 29 Mayıs 1926 y1lında Meclise sunuldu. ${ }^{50}$

“Taksimat-ı Mülkîye Tetkikatının Netayici Hakkında Umumi Rapor” başlı̆̆ını taşıyan bu gerekçeye göre; ülke dahilinde yapılan uzun incelemelerin sonunda "bugün vilayet unvanı altında sıralanmış olan büyük cüz'ü idarîler[in]" bir kısmının vilayet olmak için gerekli şartları taşımadığı tespit edilmişti. Bu tür vilayetlerin gelirleri masraflarına yetmemekte dolayısıyla da Cumhuriyet rejiminin hedeflediği bayındırlık faaliyetlerinin gerçekleşmesi mümkün olamamaktaydı. Hatta bu tür vilayetlerde; vilayet bütçesinden ödenmesi gereken bazı memurların maaşları dahi zamanında ödenememekte ve bu durum, "hükümetin şeref ve itibarını" haleldar edecek "tesirat-ı muzıraya" neden olmaktaydı. Bu sıkıntıların çözümü, yan yana bulunan küçük vilayetlerin birbirleriyle birleştirilmeleri ya da aralarında sıkışıp kalmış oldukları büyük vilayetlerden birine bağlanmaları suretiyle giderilebilirdi. Bu noktadan hareketle de kanun tasarısında; Üsküdar, Beyoğlu, Çatalca, Gelibolu, Genç, Ergani, Ardahan, Siverek, Kozan, Muş ve Dersim olmak üzere toplam on bir vilayetin kaldırılması ve "kaza" haline indirilmesi teklif edilmekteydi. ${ }^{51}$

Kanun tasarısı ile ilgili Mecliste yapılan görüşmelerde Dahiliye Vekili Cemil Bey hükümet adına açıklamalarda bulundu. Cemil Bey yaptığı konuşmada; Cumhuriyet rejiminin, mahallî idareleri kuvvetlendirmek ve merkeziyetçiliği azaltmak gayesini güttüğünü, nitekim müstakil ve mülhak livaların tamamına vilayet unvanı vererek ve vilayet meclislerinin mahallî işlerle ilgili yetkilerini arttırarak bu doğrultuda önemli adımlar attığını belirterek söze başladı. Ancak vilayet unvanı alan bazı yerlerin nüfuslarının azlığı, gelir kaynaklarının yetersizliği, iki büyük vilayet arasında sıkışmış olması gibi bir takım sebeplerden ötürü, kendilerine tevdi edilen işleri başaramadıklarından yakındı. Buna örnek olarak da Dersim'i gösterdi. Şöyle diyordu Vekil Bey;

“...Dersim elli bu kadar sene evvel liva olmuştur. Mülhak liva, müstakil liva ve en sonra da vilayet olmuştur, şahsiyet-i hükmiyesi vardır, kendi kendini idare için her türlü salahiyet verilmiştir. Fakat maalesef bir mektep açamamış, bir karış yol yapamamıştır. Binaenaleyh, Dersim'in bu yollarını yaparak, mekteplerini açarak ve bunların elinden tutarak [Cumhuriyet rejiminin] istediği gayeye götürmek için büyük, kuvvetli ve zengin kazalarının raptedilmesi uygun görülmüş̧ür. Bu sistemin daha faydalı netice vereceği zannolunmaktadır. ${ }^{52}$,"

\footnotetext{
${ }^{47}$ Heyetler, biri Dahiliye, biri Müdafaa Milliye biri de Ticaret Vekaleti'nden olmak üzere toplam üç kişiden oluşacaktı. Ülke 15 mıntıkaya bölünecek ve heyetlerden her biri bir mıntıkaya gidecekti. "Cemil Bey'in Beyanatı", Cumhuriyet, 13 Nisan 1925, s.2. Örneğin 14. Heyet; Üsküdar, Bursa, Bilecik, Kütahya, Eskişehir vilayetlerini; 15. Heyet ise İstanbul-Trakya bölgesini incelemekle görevlendirilmişti. "Tetkikat-1 Mülkîye”, Cumhuriyet, 4 Haziran 1925 , s. 1.

48 “Tetkik Heyetleri”, Hakimiyeti Milliye, 21 Mayıs 1925, S.1430, s. 1.

49 “Taksimat-1 Mülkîye”, Hakimiyeti Milliye, 29 Teşrinievvel (Ekim) 1925, S.1565, s. 1.

${ }^{50}$ TBMMZC, D.2, C.25, TBMM Matbaas1, yy. yok, Ankara, s. 612-613.

51 “Teşkilat-1 Mülkîye Tetkikatının Netayici Hakkında Umumi Rapor” TBMMZC, D.2, C.25, Sıra No:199, s.136, 137.

${ }^{52}$ TBMMZC, D.2, C.25, s. 611.
} 
Anlaşılan o ki mülkî taksimatta yaşanan sıkıntılar; vilayet idarelerinin yetkilerinin arttırılması suretiyle; "halkçı", "sorunları mahallînde çözen", "kendi mahallî işlerini kendileri gören" adem-i merkeziyetçi bir idare kurma projesinin de başarısızlığını beraberinde getirmiş; Cumhuriyet yönetiminin gerçekleştirmeyi hedeflediği kalkınma hamlelerinin gerçekleşmesi noktasında sorunlar ortaya çıkmaya başlamıştı.

Hükümet sorunu çözebilmek için yeniden geniş vilayetler kurmak istiyordu. Ancak bu konuda Mecliste bir fikir birliği olduğunu söylemek güçtür. Nitekim Erzurum milletvekili Münir Hüsrev Bey; "Dersim'i parçalayıp da bir kısım kazası bir vilayete ve bir kısmı diğer vilayete verilecek olursa zannederim Dersim'de temin-i idare, temin-i asayiş çok müşkül olur... Bu, çok muhtac-ı tetkik bir meseledir. Vekil beyefendiden çok rica ediyorum iyi tetkik buyursunlar." sözleriyle bazı vilayetleri kaldırmanın idarî ve inzibati açıdan sıkıntılar yaratacağını ileri sürdü ve Teşkilat-ı Mülkîye Kanunu'na karşı olduğunu dile getirdi. ${ }^{53}$

Bazı milletvekillerinin tasarıya yönelttiği eleştirilere ve karşı çıkışlara rağmen, tasarı Mecliste kabul edildi ve Türkiye'deki vilayet sayısı 74 'den 63 'e indirildi. ${ }^{54}$

\section{Kanunun Kabulünden Sonraki Gelişmeler}

Taksimat-1 Mülkîye Kanunu, Türkiye'de mülkî taksimat alanında yaşanan sıkıntıları çözme noktasında bir kapı aralamıştı. Hükümetin niyeti; bu süreci devam ettirerek daha rasyonel bir mülkî taksimat yapmak, böylece küçük vilayet sisteminin yarattığı sıkıntıları tamamen ortadan kaldırmak; ülkedeki idare teşkilatını, daha düzgün işlemesini sağlayacak şekilde, yeniden yapılandırmaktı. Nitekim tasarı hakkında Dahiliye Encümenince yazılan mazbatada encümenin; "vilayet adedinin idare-i umumiyede intizamı ve idare-i mahallîyede muvaffakiyeti temine imkanbahş olacak miktarda tenzilini ...şiddetle arzu etti[ $\breve{g} i$ ], " fakat zamanın darlığından dolayı şimdilik 11 vilayet için bunun uygulama mevkiine konulabildiği açıklanıyordu. ${ }^{55}$ Fakat bu değişikliğin yapılabilmesi için bir hayli zamana ihtiyaç vardı. İşte bu nedenle Teşkilat-1 Mülkîye'nin kabulünden kısa bir süre sonra Cumhuriyet yöneticileri; "Vilayetler arasindaki ortak menfaatlerin gerektirdiği işleri mahallerinde incelemek ve gereken çallşmaları organize etmek" için "asayiş ve inzibat, iktisat ve menafii müşterekesi hasebiyle bir kül arzeden vilayetlerin bir merkezden teftişs ve murakabesi imkanını bahşeden umumi müfettişlik teşkilatı"nı uygulamaya koydu. ${ }^{56}$

Umumi Müfettişlik, vilayet sayılarının azaltılması projesinin uygulamaya geçirilmesine kadar geçecek sürede görev yapmak üzere düşünülen geçici bir teşkilat olarak görülmekteydi. ${ }^{57}$

\footnotetext{
${ }^{53}$ TBMMZC, D.2, C.25, s. 607, 611.

${ }^{54}$ Kanun maddeleri hakkında için bkz., Maliye Bakanlığı Bütçe ve Mali Kontrol Genel Müdürlüğü, age., s. 410412.

55 "Teşkilat-1 Mülkîye Hakkında Başvekaletten Gelen 1/955 Numaralı Kanun Layihası ve Dahiliye ve Muvazenei Maliye Encümenleri Mazbataları”, TBMMZC, D.2, C.25, Sira No: 199, s. 141.

${ }^{56}$ TBMMZC, D.2, c.33, s. 682, 683.

${ }^{57}$ Nitekim bu durum, Umumi Müfettişlik Teşkiline Dair Kanun Tasarısı hakkında Dahiliye Encümeninin yazdığ raporda, şu sözlerle ifade edilmişti; "Livaların ...vaziyeti coğrafiye ve münasebatı iktisadiyelerine nazaran icap edenlerin yekdiğeriyle birleştirilerek [büyük] vilayetlerin teşkili ve adetlerinin tenkisi, idare-i umumiye ve hususiyeleri itibarile lazım olduğu kadar, Teşkilatı Esasiye Kanunumuzun ruhuna da muvafik-ı hareket olur...Bu teşkilatın az zamanda icrasına imkan olmadı̆̆ını nazarı itibara alan Dahiliye Encümeni, asayiş ve inzibat, iktisat ve menafi-i müşterekesi hasebiyle bir kûl arz eden vilayetlerin bir merkezden teftiş ve murakabesi imkanını bahşeden Umumi Müfettişlik Teşkilatı hakkındaki tasarıyı bazı tadilat icra ederek kabul etmişstir."

Bütçe Encümeninin hazırladığı mazbatada ise şöyle denilmişti:

"Esasen Umumi Müfettişlik derecat-ı idarîyeden madut olmayıp, bu suretle temin edilecek menafi daha ziyade muvakkat bir zamana ve fevkalade ihtiyacata münhasır kalacağından vilayetler teşkilatının ıslahının daha umumi ve daimi bir tedbir olacağl şüphesizdir. Ancak vilayetler teşkilatında ıslahat yapmak esasl tetkikata ve bir hayli zamana tevakkuf edeceği cihetle umumi müfettişlik teşkilatiyle bu ihtiyacatın karşılanması zaruri addedilmiş_tir]."
} 
Nitekim teşkilatın kurulmasının ardından, ülkedeki vilayet sayısını azaltma doğrultusunda bir takım çalışmalar yapılmaya başlandı. Bu kapsamda 1931 yılında Dahiliye Vekaleti tarafından konuyla ilgili bir rapor da hazırlandı.

Raporda, öncelikle mülkî taksimatın dönem içinde geçirdiği evreler ve halihazırdaki küçük vilayetlere dayalı sistemin yarattığı sıkıntılar sıralanıyor; adından da Türkiye'deki mevcut 63 vilayetin 17'si kaldırılarak vilayet sayısının 46'ya indirilmesini öngören proje sunuluyordu. Raporda kaldırılması teklif edilen vilayetlerin çoğunun hususi gelirlerinin vilayetlere tevdi edilen mahallî işleri yapmalarına olanak sağlamayacak derecede düşük olduğu, bunların kaza haline indirilerek büyük vilayetlere bağlanmalarıyla vilayet özel idarelerinin başarılarının da artacağı açıklanıyordu. ${ }^{58}$

Fakat tüm bu raporlara, programlara, projelere rağmen Türkiye'de vilayet sayılarını azaltma projesi uygulamaya konul(a)madı. Zira bir yandan bu konuda Mecliste bir fikir birliği yoktu, diğer yandan bazı vilayetlerin nüfus ve gelir bakımından vilayet olmaya elverişli olmamalarına rağmen güvenlik kaygıları nedeniyle vilayet olarak kalmasında fayda görülüyordu.

Ayrıca bazı vilayetlerin kaldırılarak başka vilayetlerle birleştirilmesi düşüncesi halk tarafindan da benimsenmemekte, vilayet vasfi ortadan kalkacak olan mahallerde yaşayan ahali bu duruma ciddi tepki göstermekteydi. ${ }^{59}$

Hal böyle olunca da 1927 yılında geçici bir teşkilat olması düşünülerek uygulamaya konulan umumi müfettişlik, ülke geneline yaygınlaştırılmaya ve giderek idarî sistemde kalıc1 bir teşkilat haline gelmeye başladı ${ }^{60}$ Ancak bu gelişme, bir takım başka sıkıntıların çıkmasına neden oldu. Nitekim müfettişlik teşkilatı, idare mekanizması içerisinde geçici bir ara kurum olarak düşünüldüğünden ve ayrıca üç dört vilayetin birleşimiyle oluşturulan umumi müfettişlik mıntıkaları, mülkî taksimat içerisinde bir cüz'ü tam olarak kabul edilmediğinden dolayı, valilerle umumi müfettişlerin yetki çatışması yaşanmaya; vilayetler ile umumi müfettişlik mıntıkaları arasındaki coğrafi karışıklıklar ortaya çıkmaya başladı. ${ }^{61}$

Süreç içerisinde birbiriyle çelişen adımlar atılmaya devam edildi. Nitekim 20 Mayıs 1933 tarihinde 2197 sayılı kanun çıkarılarak; İçel, Hakkari, Artvin, Aksaray, Cebelibereket ve Şebinkarahisar olmak üzere toplam 6 vilayet kaldırılır ve Türkiye'deki vilayet sayısı 57'ye indirilirken; ${ }^{62}$ Aralık 1935 'te 2885 sayılı kanun çıkarılarak; Çoruh, Hakkari, Bitlis, Bingöl ve

Bkz., "Umumi Müfettişlik Teşkili Hakkındaki Kanun Layihası Hakkında Dahiliye ve Bütçe Encümenleri Tarafından Hazırlanan Mazbatalar", TBMMZC, D.2, c.33, s. 683-684.

58 BCA, Başbakanlık Muamelat Genel Müdürlüğü Kataloğu (BMGMK), Cumhurbaşkanının Yaptığ Yurtiçi Gezilerde Dahiliye Vekaletini İlgilendiren Konularda Kendisinin Verdiği Direktifler Çerçevesinde Bu Vekalet Tarafindan Hazırlanan Dokuz Adet Rapor, FK: 30.10.0.0, Yer No: 2.11.1, Tarih: 05.05.1931.

59 Nitekim 1928 yılında gazetelerde bazı vilayetlerin kaldırılacağı yolunda bir takım haberler çıkınca halk TBMM'ye yapılmak istenen girişimle ilgili şikayet telgrafları göndermişti. Bkz., TBMMZC, D.3, C.3, TBMM Matbaas1, yy. yok, s. 266.

${ }^{60}$ Nitekim Mart 1935 ’te; Edirne, Kırklareli, Tekirdağ ve Çanakkale vilayetlerini kapsayan bölgede görev yapmak üzere II. Umumi Müfettişlik; Ağustos 1935'te Erzurum, Erzincan, Trabzon, Ağrı, Gümüşhane, Kars, Artvin vilayetlerini kapsayan bölgede görev yapmak üzere III. Umumi Müfettişlik; Aralık 1935 'te ise Tunceli, Elazığ ve Bingöl vilayetlerini kapsayan bölgede görev yapmak üzere IV. Umumi Müfettişlik kuruldu. Ancak belirtmek gerekir ki özellikle Doğu ve Güneydoğu Anadolu bölgelerinde görev yapacak Umumi Müfettişlikler sadece küçük vilayet sisteminden kaynaklı iktisadî sıkıntılara bir çözüm olarak değil, aynı zamanda iç güvenlik açısından da görevler yüklenen teşkilatlardı.

${ }^{61} \mathrm{Bu}$ konuda ayrıntılı bilgi için bkz., Murat Burgaç, Türkiye'de Umumi Müfettişsliklerin Kurulması ve Trakya Umumi Müfettişliği, Atatürk Araștırma Merkezi Yayınları, Ankara 2013.

${ }^{62}$ Düstur, üçüncü tertip, C.14, Başvekalet Devlet Matbaası, Ankara 1954, s. 241-242. 
Tunceli olmak üzere 5 yeni vilayet kuruldu ve Türkiye'deki vilayet sayısı yeniden 62 'ye çıkarıld1. ${ }^{63}$

Böylece, Türkiye'de mülkî taksimatın yeniden düzenlenmesi, gündemdeki yerini sürekli koruyan ve fakat bir türlü çözülemeyen bir mesele olarak kalmaya devam etti.

\section{Sonuç}

Türkiye'de, vilayet idareleri ve mülkî taksimat konularında oluşmuş olan literatürde; 1921 Anayasası'nda vilayet idarelerine verilen geniş yetkilerin, ilerleyen tarihlerde peyderpey geri alınması ve daha merkeziyetçi bir yapıya gidilmesinin nedeni, genellikle, Cumhuriyet yöneticilerinin başından beridir adem-i merkeziyetçi bir yap1 istemedikleri görüşü ile açıklanmaktadır. Bu görüşe göre; 1921 Anayasası'nda vilayetlere idarî adem-i merkeziyetçilik verilmesinin altında yatan temel etken, ulusal bağımsızlık savaşı sürecinde ülkede geniş bir koalisyon oluşturabilmek, daha açık bir ifadeyle Kürt aşiretlerini "kontrol altında" tutabilmektir. Bu görüşün taraftarları, yeni devletin kurucularının zaten hiçbir zaman 1921 Anayasası hükümlerini uygulamaya koyma niyetleri olmadığını iddia etmektedir. ${ }^{64}$ Ancak incelenen dönem içerisinde varılan bulgular, bu denli kesin yargıları sorgulamak gerektiğini ortaya koymaktadır.

HISTORY

STUDIES

87

Volume 11

Issue 1

February

2019

$\mathrm{Bu}$ makalede örnekleri verildiği üzere, 1921 Anayasası'nın kabulünden sonra Mecliste konuyla ilgili yapılan tartışmaların tümünde; vilayet idarelerinin yetki ve sorumluluğuna devredilen işlerin yerine getirilemediği gerçeği karşımıza çıkmaktadır. Bunun nedeni ise; 1921 Anayasası'nda, her livanın bir vilayet kabul edilmesi ve böylece ülkede malî kaynakları yetersiz pek çok küçük vilayetin kurulmuş olmasıdır. Kanımızca yeni devletin kurucularını daha merkeziyetçi bir vilayet idaresi kurmaya sevkeden saik, bunu istemelerinden ziyade, şartların zorlamasıdır ve altında yatan temel etken de ülkedeki mülkî taksimatın rasyonel bir şekilde yapılandırıl(a)mamasıdır. Nitekim sadece I. Meclis döneminde değil, Cumhuriyetin ilanından sonra da merkeziyetçi bir idarî yapıya taraftar olmadıklarına dair pek çok örnek bulmak mümkündür. Örneğin 1929 yılında çıkarılan “Vilayet İdaresi Kanunu”nun gerekçesinde şöyle denilmektedir:

"Demokrasi umdeleri, mutlak idareler gibi sıkı merkeziyetin de amansız düşmanıdır. Bu umdeleri kabul eden memleketler, merkeziyet ve adem-i merkeziyet esasların da eyi ve muvazeneli bir şekilde idarelerinde tatbik etmis ve bu sebeble; nafia, maarif, ziraat, ticaret ve iktisat sahalarında çok ilerlemiş, yardıma ve bakıma muhtaç vatandaşlar için bir çok sıhhî ve içtimaî müesseseler açmışlardır. Merkeziyet usulünün zararlarını bu gün ancak bu memleketlerin tarihlerinde ve bilhassa bizim idare tarihimizde okuyabiliriz. ${ }^{65}$ ",

Dönemin Dahiliye Vekili Şükrü (Kaya) bu kanunun Meclisteki görüşmeleri sırasında yaptığı konuşmada; "Cumhuriyet ve Demokrasi usullerile idare olunan memleketlerde mahalli idareler hakkında varit olabilecek makbul ve makul mülahaza ve mütalaalar yalnız ve yalnız onların muhafazasina ve takviyesine matuf olabilir. ${ }^{66 " ~ s o ̈ z l e r i y l e ~ h u ̈ k u ̈ m e t i n ~ b u ~ k o n u d a k i ~}$ düşüncesini net bir şekilde ortaya koymaktadır. ${ }^{67}$

\footnotetext{
${ }^{63}$ Düstur, üçüncü tertip, C.17, Başvekalet Devlet Matbaası, Ankara 1936, s. 171.

${ }^{64}$ Bir örnek için bkz., Nizam Önen-Cenk Reyhan, Mülkten Ülkeye Türkiye'de Taşra İdaresinin Dönüşümü (18391929), İletişim Yayınları, İstanbul 2011, s. 421-422, 454-455.

65 "Vilayetlerin Umumi İdaresi Hakkında 1/352 Numaralı Kanun Layihası ve Muhtelit ve Bütçe Encümenleri Mazbataları", TBMMZC, D.3, C. 10, Sira No:134, TBMM Matbaas1, Ankara yy. yok, s. 6.

${ }^{66}$ TBMMZC, D.3, C. 10 , s. 431.

${ }^{67}$ Cumhuriyet idarecilerinin konuyla ilgili benzer görüşleri için bkz., BCA, BMGMK, FK: 30.10.0.0, Yer No: 2.11.1, Tarih: 05.05.1931. Ayrıca bkz., BCA, BMGMK, CHP Grubu Mahallî İdareler Encümeni Raporu, FK: 30.10.0.0, Yer No: 67.445.4, Tarih: 06.06.1937.
} 
$\mathrm{Bu}$ ve buna benzer pek çok örnekte karşımıza çıkan gerçek şudur ki; Cumhuriyet yöneticileri merkeziyetçi bir idarî yapı kurmayı hedeflemek bir yana; böyle bir yapıyı demokrasinin ve ilerlemenin önündeki en büyük engel olarak görmüşler ve mahallî idareleri güçlendirmek suretiyle, bu yapıyla hesaplaşmayı ve yıkmayı amaçlamışlardır. Vilayetlerin tüzel kişiliğinin tanınmasının ve Vilayet Meclislerine mahallî işler ile ilgili yetki ve sorumluluk verilmesinin altında yatan temel neden de budur. Ancak fiiliyatta bu amacin gerçekleştirilemediği görülmektedir. Zira bu amaca ulaşabilmek, güçlü bütçelere sahip vilayetlerle mümkündür. Oysa ki 1921 Anayasası ile kabul edilen mülkî taksimat, az nüfuslu ve mali açıdan yetersiz vilayetler ortaya çıkarmış ve bu vilayetlerin pek çoğu kendi yetki ve sorumluluklarına devredilen eğitim, bayındırlık, imar gibi işlerde başarı gösterememişlerdir. ${ }^{68}$ $\mathrm{Bu}$ durum, ülkenin her tarafında hızlı bir kalkınma ve modernleşme hamlesi yürütme amacında olan Cumhuriyet yöneticileri için büyük bir sorundur. Sorun, mülkî taksimatın yeniden ve rasyonel bir şekilde yapılandırılması suretiyle çözül(e)meyince; vilayetlerin yetki ve sorumluluğuna bırakılan mahallî işler süreç içerisinde merkezi idarenin yetkisine devredilmiş̧ ${ }^{69}$ mahallî idareleri güçlendirmek düşüncesi ile çıkılan yolda geriye gidişler yaşanmış ve giderek ülkede daha merkeziyetçi bir yapı ortaya çıkmıştır.

\section{Kaynakça}

Kitap ve Makaleler

BAŞGÖZ, İlhan, Türkiye’nin Eğitim Çıkmazı ve Atatürk, Kültür Bakanlığı Yayınları, Ankara 1995,

BEHLÜLGİL, Mefahir, Imparatorluk ve Cumhuriyet Dönemlerinde İllerimiz, Özal Matbaas1, İstanbul 1992.

BURGAÇ, Murat, "Osmanlı Devleti'nde Adem-i Merkeziyetçilik Tartışmaları (18761913)", Amme Idaresi Dergisi, C.51, S.2, Haziran 2018, ss.144-176.

BURGAÇ, Murat, Türkiye'de Umumi Müfettişliklerin Kurulması ve Trakya Umumi Müfettişliği, Atatürk Araştırma Merkezi Yayınları, Ankara 2013.

ÇADIRCI, Musa, Tanzimat Sürecinde Türkiye'de Ülke Yönetimi, İmge Kitabevi, Ankara 2007.

DAHILIYYE VEKALETİ, Geçen Yıllarda Yapılan ve Gelecek Yıllarda Yapılacak Olan ISşler Hülasası, Cumhuriyet Matbaası, Ankara 1938.

GÖRELİ, İsmail Hakkı, Il İdaresi, Ankara Üniversitesi Siyasal Bilimler Fakültesi Yayınları, Ankara 1952.

\footnotetext{
${ }^{68} \mathrm{Bu}$ noktada bir parantez açmak ve bazı vilayetlerde, vilayet meclislerinin yerel gerici güçlerin elinde olmasından kaynaklanan sıkıntıya da değinmek gerekir. İlkokul açma, öğretmen maaşlarını verme gibi görevlerin vilayet meclislerinin yetki ve sorumluluğunda olması, bu tür vilayetlerde eğitim işlerinin aksamasına neden olduğu da görülmektedir. $\mathrm{Bu}$ aksama bütçe yetersizliğinden ziyade, bu meclislere hakim olan güçlerin eğitime yönelik olumsuz tutumlarıdır. Cumhuriyetin ilk yıllarında Maarif Vekilliği yapmış olan Hamdullah Suphi (Tanrı̈ver), 1925 yılında verdiği bir konferansta; "Eğitim masraflarını saptayıp dağıtanlar, Vilayet Meclislerine üye olarak gelenler kimlerdir? Bu Meclislerin şimdiki örgütlenişine göre üyenin bir bölümü, halkın okumasından korkan, midesini ve kesesini bütün tufeyliler gibi büyük kitlenin cahilliği ve gafleti sayesinde doyuran kimselerdir." sözleriyle tam da bu konuya dikkat çekmektedir. Konuyla ilgili ayrıntılı bilgi için bkz., İlhan Başgöz, Türkiye'nin Eğitim Çıkmazı ve Atatürk, Kültür Bakanlığ1 Yayınları, Ankara 1995, s. 83-90.

${ }^{69}$ Vilayet Genel Meclislerinin yetki ve sorumluluğuna bırakılan işlerin süreç içerisinde merkezî hükümete aktarılması ile ilgili örnekler için bkz., Dahiliye Vekaleti, Geçen Yıllarda Yapılan ve Gelecek Yıllarda Yapılacak Olan İsler Hülasası, Cumhuriyet Matbaası, Ankara 1938, s. 40-41.
} 
İÇIŞLERİ BAKANLIĞI, I. İdareciler Kongresi, (20 Ocak 1947-31 Ocak 1947), Akın Matbaas1, Ankara 1947.

KESKİN, Nuray E. "II. Meşrutiyet’te Yeni Düzen Arayış1”, 18. Yüzyıldan 21. Yüzyıla Kamu Yönetiminde Reform, TODAİE, Ankara 2009, s.225-236.

KİLİ, Suna- Şeref, Gözübüyük, Türk Anayasa Metinleri, Türkiye İş Bankası Yayınları, İstanbul 2000.

MALIYY BAKANLIĞI BÜTÇE VE MALİ KONTROL GENEL MÜDÜRLÜĞÜ, Vilayetler ve Mahallî İdareler Mevzuatı (1864-1996), Maliye Bakanlığ Yayınları, Ankara 1997.

ORTAYLI, İlber, Tanzimat Devrinde Osmanl Mahallî İdareleri (1840-1880), TTK Yayınları, Ankara 2000.

ORTAYLI, İlber, “Türkiye'de Taşra Yönetim ve Yöneticiliğinin Evrimi”, Türkiye'de Mülkî İdare Amirliği, Editör Kurthan Fişek, Türk İdareciler Derneği Yayınları, Ankara 1976, s. 1-22.

ÖNEN, Nizam - REYHAN, Cenk. Mülkten Ülkeye Türkiye'de Taşra İdaresinin Dönüşümü (1839-1929), İletişim Yayınları, İstanbul 2011.

YAMAN, Talat Mümtaz, "Osmanlı İmparatorluğu Mülkî İdaresinde Avrupalılaşma”, İdare, , S.142, İkinci kanun (Ocak) 1940, s. 1466-1547.

Resmi Yayınlar

Düstur, üçüncü tertip, C.14, Başvekalet Devlet Matbaası, Ankara 1954.

Düstur, üçüncü tertip, C.17, Başvekalet Devlet Matbaası, Ankara 1936.

"Encümen-i Mahsus Tarafindan Tadilen Tanzim Olunan İdare-i Vilayet Kanunu Layihasiyla Esbab-1 Mucibe Mazbatası", Meclis-i Mebusan Levayih ve Tekalif-i Kanuniye ve Encümen Mazbataları (MMLTKEM), Sene: 1326-1327, Sira No: 26, TBMM Basimevi, Ankara 1992, s. 56-81.

Türkiye Büyük Millet Meclisi Zabıt Ceridesi (TBMMZC), Devre (D).1, C.5, TBMM Basımevi, Ankara 1981.

TBMMZC, D.1, C.6, TBMM Matbaası, Ankara 1943.

TBMMZC, D.1, C.12, TBMM Matbaas1, Ankara 1958.

TBMMZC, D.1, C.13, TBMM Matbaas1, Ankara 1958.

TBMMZC, D.2, C.1, TBMM Matbaası, Ankara 1961.

TBMMZC, D.2, C.4, TBMM Matbaas1, Ankara 1968.

TBMMZC, D.2, C.7, TBMM Matbaası, Ankara 1970.

TBMMZC, D.2, C.8, TBMM Matbaası, Ankara 1975.

TBMMZC, D.2, C.25, TBMM Matbaası, Ankara yy. yok.

TBMMZC, D.2, C.33, TBMM Matbaası, Ankara yy. yok.

TBMMZC, D.3, C.3, TBMM Matbaas1, Ankara yy. yok.

TBMMZC, D.3, C.10, TBMM Matbaası, Ankara yy. yok. 
Türkiye Büyük Millet Meclisi Gizli Celse Zabıtları (TBMMGCZ), D.1, C.3, Türkiye İş Bankası Kültür Yayınları, Ankara 1985.

Devlet Arşivleri Başkanlığ 1

DAB, CHPK, 490.1.0.0/ 212.840.1: Dahiliye Vekaletinin CHP Büyük Kurultayına Umumi İşler ile İlgili Sunduğu Rapor.

DAB, BMGMK, 30.10.0.0/2.11.1: Cumhurbaşkanının Yaptığ1 Yurtiçi Gezilerde Dahiliye Vekaletini İlgilendiren Konularda Kendisinin Verdiği Direktifler Çerçevesinde $\mathrm{Bu}$ Vekalet Tarafindan Hazırlanan Dokuz Adet Rapor.

DAB, BMGMK, 30.10.0.0/67.445.4: CHP Grubu Mahallî İdareler Encümeni Raporu.

Gazeteler

“Cemil Bey'in Beyanatı”, Cumhuriyet, 13 Nisan 1925.

“Tetkikat-1 Mülkîye”, Cumhuriyet, 4 Haziran 1925.

“Tetkik Heyetleri”, Hakimiyeti Milliye, 21 Mayis 1925.

“Taksimat-1 Mülkîye”, Hakimiyeti Milliye, 29 Teşrinievvel 1925. 